\title{
Scientific literature on invasive alien species in a megadiverse country: advances and challenges in Mexico
}

\author{
Jorge E. Ramírez-Albores ${ }^{1,4}$, Ernesto I. Badano', Joel Flores', \\ José Luis Flores-Flores ${ }^{2}$, Laura Yáñez-Espinosa ${ }^{3}$
}

I División de Ciencias Ambientales, Instituto Potosino de Investigación Cientifica y Tecnológica, A.C., Camino a la Presa San José 2055, Colonia Lomas 4ta Sección, C.P. 78216, San Luis Potosí, S. L.P., México 2 Instituto de Investigación de Zonas Desérticas, Universidad Autónoma de San Luis Potosí, Altair 200, Fracc. Del Llano, C.P. 78377, San Luis Potosí, S.L.P., México 3 Instituto de Investigación de Zonas Desérticas, Universidad Autónoma de San Luis Potosí, Altair 200, Fracc. Del Llano, C.P. 78377, San Luis Potosí, S.L.P., México 4 Museo de Zoologia "Alfonso L. Herrera", Departamento de Biología Evolutiva, Facultad de Ciencias, Universidad Nacional Autónoma de México. Apartado Postal 70-399. Ciudad de México, 04510, México

Corresponding author: Jorge E. Ramirez-Albores (jorgeramirez22@hotmail.com)

Academic editor: M. von der Lippe | Received 14 May 2019 | Accepted 1 July 2019 | Published 16 July 2019

Citation: Ramírez-Albores JE, Badano EI, Flores J, Flores-Flores JL, Yáñez-Espinosa L (2019) Scientific literature on invasive alien species in a megadiverse country: advances and challenges in Mexico. NeoBiota 48: 113-127. https://doi. org/10.3897/neobiota.48.36201

\begin{abstract}
Interest in invasive species has increased around the world over the last several decades. In Mexico, studies on invasive species date as early as 1939 and the number of publications has increased considerably in recent decades. However, to our knowledge, the analysis of information gaps and research priorities is lacking. Therefore, it is necessary to identify gaps in the knowledge of invasive species in order to define future research priorities and focus conservation efforts. We assessed the current state of knowledge of biological invasions in Mexico based on the existing literature. Our aim was to identify in which areas information is absent or insufficient and which areas should be prioritised. We identified a total of 869 references. The number of references increased over time and the topics were strongly biased towards two areas: 1) natural history and geographical distribution patterns and 2) effects on native biota and ecosystems. The remaining topics were only moderately or poorly studied. Most studies focused on vascular plants $(n=280)$ and fishes $(n=174)$. Notably, a large portion of the references $(n=215)$ focused on only eight invasive alien species, including their ecological and socioeconomic impacts. Only 95 references examined the effects of alien species on biodiversity; these studies were mainly carried out on islands $(n=41)$ or in terrestrial or freshwater ecosystems in protected natural areas $(n=165)$. The findings of the
\end{abstract}

Copyright Jorge E. Ramírez-Albores et al. This is an open access article distributed under the terms of the Creative Commons Attribution License (CC BY 4.0), which permits unrestricted use, distribution, and reproduction in any medium, provided the original author and source are credited. 
present review can guide future studies in filling in the existing research gaps on biological invasions. Additionally, future studies should aim to define national priorities of the impacts of biological invasions and to promote the prevention and control of alien species by considering the distinct vectors and pathways of introduction and movement.

\section{Keywords}

Alien species, invasive species, megadiverse, scientific references

\section{Introduction}

The movement of species by humans has been a common practice since the origins of agriculture and cattle raising. Since the European colonisation in the $16^{\text {th }}$ century, this practice has intensified as a result of increased commercial exchange across different regions of the world (MacIsaac et al. 2011). In this regard, alien species are defined as those moved by human activities beyond the limits of their native geographic ranges to areas where they do not naturally occur. Movement by humans allows species to overcome fundamental biogeographic barriers to their natural dispersal (Richardson et al. 2011). However, invasive species are one of the major environmental concerns of the globalisation era because of their detrimental effects on native biodiversity and economic activities (D'Antonio and Vitousek 1992; Wilcove et al. 1998; Charles and Dukes 2007).

The publication of Charles Elton's book The Ecology of Invasions by Animals and Plants (Elton 1958) sparked greater interest in invasive species in the ecological sciences, as researchers aimed to determine which characteristics make certain species better invaders than others (Rejmănek and Richardson 1996; Heenan et al. 1998; Pyšek and Richardson 2006). In this regard, the population dynamics of invasive species that aggressively colonise new sites can provide valuable information on how to counter the potentially detrimental effects on biodiversity and economic activities. However, one current challenge facing many countries is simply the assessment of the number of alien species within their borders, including which species have become naturalised and which have the potential to become invasive. This is a particularly key issue for megadiverse countries that cover less than $10 \%$ of the Earth's surface yet contain up to $70 \%$ of the Earth's biota (Mittermeier et al. 1997; Challenger and Caballero 1998). In these regions, biological invasions can strongly threaten the environmental goods and services provided by biodiversity (Vitousek 1990; Charles and Dukes 2007). In developed megadiverse countries, such as the United States, biological invasions currently constitute one of the largest threats to biodiversity after land use change (Wilcove et al. 1998). Nevertheless, little is yet known about the impacts of biological invasions in countries with emerging economies (Nuñez and Pauchard 2010), including the megadiverse countries of Latin America: Mexico, Brazil, Colombia, Ecuador and Venezuela (Challenger and Caballero 1998). Definitively, the introduction of alien species in the Americas has gradually occurred since the arrival of the European colonisers. In the recent era of globalisation, international trade and exchange have intensified the introduction of alien species (Meyerson and Mooney 2007). 
Mexico contains $10 \%$ of the Earth's species diversity and harbours the largest diversity of ecosystems in the world (Challenger and Caballero 1998). However, the progressive economic development of Mexico is expected to increase the rate of introduction of alien species, which may threaten the stability and integrity of ecosystems in the short term, as has occurred in other countries (Lin et al. 2007; Meyerson and Mooney 2007). In 2018, the National Commission for the Knowledge and Use of Biodiversity of Mexico (CONABIO) indicated that > 300 alien species are present in the country, threatening both the economy and biodiversity. Nevertheless, these estimations may be inaccurate because scientific studies assessing the spreading of alien species in Mexico are scarce (Espinosa-García 2008), even though more information exists for Mexico than most Latin American countries (e.g. CONABIO). This is likely due to the priorities of developing nations, which are generally focused on governance issues (e.g. social development and industrialisation) rather than biodiversity conservation.

Therefore, the aims of the present article were to compile the first comprehensive list of references on biological invasions in a megadiverse country as Mexico, to provide an analysis of the encountered trends and to identify advances in the scientific knowledge of invasive species. We performed an extensive review of references relating to biological invasions in Mexico from 1910 to 2018. We additionally sought to answer the following questions: Is biological invasion research in Mexico following worldwide trends regarding the number of publications over time; which species group has been most studied; what types of references are most frequent; which topics are studied most intensively; what is the scope of existing studies; and finally, which Mexican regions are studied more intensively? This information will enable researchers to understand the current state of knowledge of biological invasions in Mexico and prioritise future research on the subject. Furthermore, it can help guide public policies regarding biological invasions in Mexico in order to prevent, or at least mitigate, the impacts of invasive species on native biota, natural ecosystems and productive human activities.

\section{Methods}

An extensive search was conducted of literature published on biological invasions in Mexico. Several academic databases were searched to gather the most information possible, considering both indexed and non-indexed publications in both English and Spanish. The searched databases included the following: Web of Knowledge ( Thomson Reuters), Scopus (Elsevier), Current Contents Connect (Thomson Reuters), Biological Abstracts (Thomson Reuters), Zoological Record (Thomson Reuters), the Journal Storage Project-JSTOR (ITHAKA), Google Scholar (Google), the Scientific Electronic Library Online ( BIREME-OPS-OMS) and the Network of Scientific Journals from Latin America and the Caribbean and from Spain and Portugal ( Redalyc-Universidad Autónoma del Estado de México). In each database, an extensive search of bibliographic references was performed using combinations of the following keywords: biological invasion OR invasion OR invasive OR invasiveness OR invader OR naturalised OR 
introduced OR alien OR exotic OR non-native OR feral OR non-indigenous OR pest OR ruderal OR weed in addition to AND Mexico or AND Mexican.

Several filters were applied: (i) Only publications (based on the title) in the research areas of agronomy, biology, biodiversity conservation, ecology, entomology, environmental sciences, fisheries, forestry, marine freshwater sciences, plant sciences and zoology were included in the present review. (ii) Numerous types of documents were considered, including scientific articles, reviews, books, book chapters, theses, technical brochures, conference proceedings and divulgation articles. We searched for theses, technical reports and conference proceedings in the bibliographic repositories or electronic databases of different universities and research centres in Mexico. (iii) All searches were conducted, based on the content of the titles and abstracts. The keywords in English, as well as their translations into Spanish, were searched in the databases. (iv) Only documents focusing in their entirety on the topics of biological invasion, invasion, invader, invasive species and invasiveness were considered, excluding misquoted or incomplete references. $(v)$ Additionally, literature that addressed biological invasions or projections at a regional or global level that included Mexico were considered, i.e. studies by researchers from other countries addressing global patterns of invasion. ( $v i$ ) Finally, we excluded literature under review and reports on informal websites, such as personal blogs and webpages without affiliations to academic or government institutions. Repeated titles were discarded, as some references, for example, were presented in more than one congress or were published as both a thesis and a scientific article. A total of 869 documents were returned in the search and were carefully reviewed and included in the present study, based on the above-described criteria. To identify the scientific trends in the compiled references, we classified them according to the criteria listed in Table 1. Finally, in order to determine significant heterogeneity between publication type and species group, main topic and scope of the study (see Table 1), a chi-square test for "goodness of fit" was made (Zar 1999).

\section{Results}

The literature search generated 869 references from the year 1910 to 2018 that complied with the established criteria (Table 1, Suppl material 1: Appendix S1). Most references were scientific articles $(\mathrm{n}=324)$ followed by conference proceedings $(\mathrm{n}=$ $261)$ and scientific books and book chapters $(n=139)$. Although most references were scientific publications (i.e. scientific articles), only 244 were published in journals catalogued in the 2018 Journal Citation Reports (i.e. Journal Citation Reports provides information about the academic journals with the highest impact, value and scientific contribution). Regarding temporal trends, exponential growth occurred in the number of scientific references over time, especially scientific articles and conference proceedings (Fig. 1). Of these references, 280 were studies on vascular plants and 174 on fishes; the remainder were on other species groups (Table 2). The relative importance of species groups varied significantly amongst reference types, with significant heterogeneity 
Table I. Criteria for classifying references on biological invasions in Mexico and identifying scientific trends.

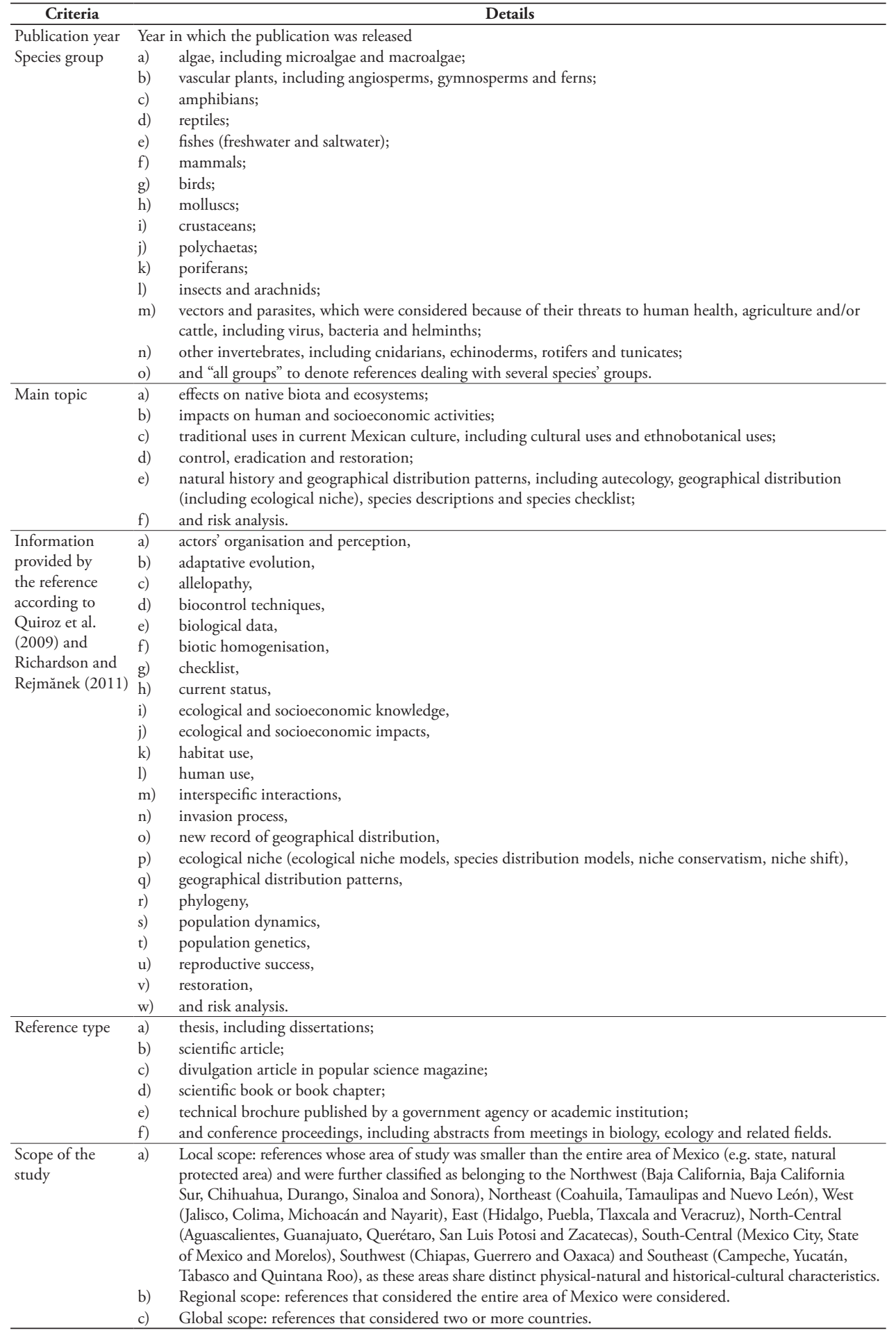



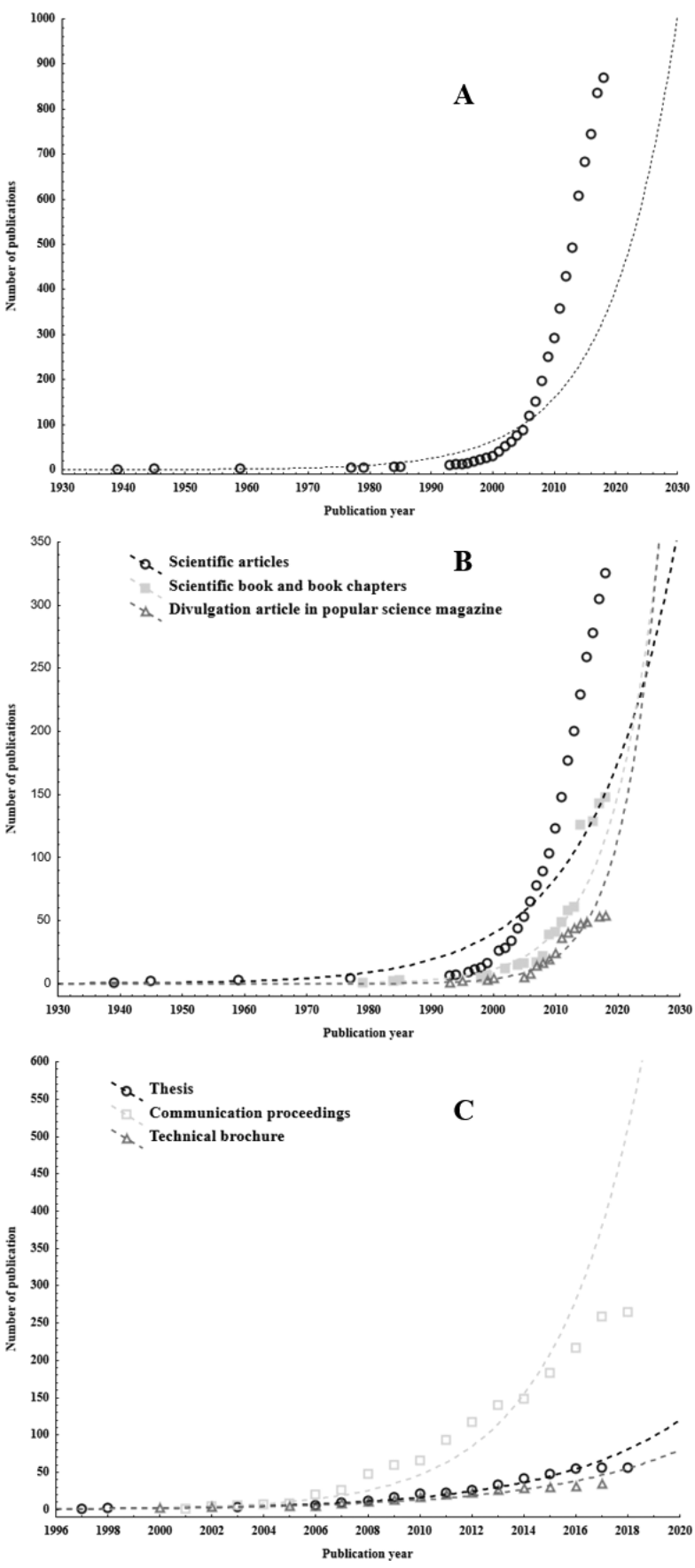

Figure I. References on biological invasions in Mexico during the 1910-2018 period. The curves show exponential growth (dotted line): A total references $\left(r^{2}{ }_{a d j}=0.34, p<0.001\right)$ B scientific articles $\left(r_{a d j}^{2}=0.37, p<0.001\right)$, scientific books and book chapters $\left(r_{a d j}^{2}=0.46, p<0.001\right)$ and divulgation articles in popular science magazines $\left(r_{a d j}^{2}=0.79, p<0.001\right) \mathbf{C}$ technical brochures $\left(r_{a d j}^{2}=0.99, p<0.001\right)$, conference proceedings $\left(r_{\text {adj }}^{2}=0.86, p<0.001\right)$ and theses $\left(r^{2}{ }_{a d j}=0.80, p<0.001\right)$. 
Table 2. Distribution of references on biological invasions in Mexico per species group.

\begin{tabular}{|c|c|c|c|c|c|c|}
\hline & Scientific article & $\begin{array}{l}\text { Scientific book and } \\
\text { book chapter }\end{array}$ & $\begin{array}{c}\text { Divulgation article } \\
\text { in popular science } \\
\text { magazine }\end{array}$ & Thesis & $\begin{array}{l}\text { Conference } \\
\text { proceedings }\end{array}$ & $\begin{array}{l}\text { Technical } \\
\text { brochure }\end{array}$ \\
\hline Algae & 16 & 3 & 1 & 1 & & 1 \\
\hline Amphibians & 7 & 1 & 1 & & 3 & \\
\hline Birds & 38 & 1 & 3 & 3 & 31 & \\
\hline Crustaceans & 8 & 3 & & 2 & 1 & 1 \\
\hline Fishes & 58 & 28 & 10 & 11 & 62 & 5 \\
\hline Insects and arachnids & 47 & 3 & 5 & 5 & 13 & 1 \\
\hline Mammals & 12 & 9 & 3 & 6 & 15 & 2 \\
\hline Molluscs & 14 & 2 & 2 & & 4 & \\
\hline Other invertebrates & 4 & 2 & & 1 & 2 & \\
\hline Polychaetas & 1 & 4 & 1 & & 1 & 1 \\
\hline Reptiles & 7 & 1 & & 1 & 5 & 1 \\
\hline Vascular plants & 100 & 22 & 14 & 22 & 101 & 14 \\
\hline Vectors and parasites & & 1 & & 1 & & \\
\hline All groups & 2 & 37 & 12 & 1 & 15 & 5 \\
\hline
\end{tabular}

(chi-square $=107.16, d f=11, p<0.001$ ), due to over-representation references on vascular plant and fishes while amphibians, reptiles, crustaceans, polychaetas, molluscs and other invertebrates were under-represented.

Of the compiled references, 377 focused on the natural history and geographic distribution patterns of invasive species and 203 on risk analysis. The remainder corresponded with other topics (Fig. 2A). The relative importance of these topics varied significantly amongst reference types, with significant heterogeneity amongst reference types in the focus of study (chi-square $=192.26, d f=3, p<0.001$ ), largely as a result of scarce studies on the control, eradication and restoration and effects on native biota and ecosystems. The most studied topic were: actors' organisation and perception, biocontrol techniques, current status, ecological and socioeconomic impacts, geographical distribution patterns, interspecific interactions, new records of geographical distribution and risk analysis (Table 3); the least studied topics were the phylogeny, habitat use, biotic homogenisation and allelopathy of invasive species (Table 3).

Only 94 references addressed the effects of alien species on biodiversity; nearly half of these studies $(\mathrm{n}=41)$ were carried out on islands (e.g. Socorro Island, Cozumel Island, Guadalupe Island and Santa Catalina Island, amongst others). These latter studies on islands mostly focused on the introduction, control and eradication of invasive species, including reptiles and feral mammals (cats, mice, goats, sheep, rats and dogs) that had led to the near extinction of different native species of birds, mammals and reptiles. Few studies focused on terrestrial or freshwater ecosystems, particularly in protected natural areas $(\mathrm{n}=164)$.

Regarding damage to socioeconomic activities, the Cactus moth (Cactoblastis cactorum) was identified as one of the most dangerous agricultural pests in Mexico with disastrous effects. Additional invasive species with documented harmful effects include Buffelgrass (Pennisetum ciliare) and the Red-bay ambrosia beetle (Xyleborus glabratus), which 


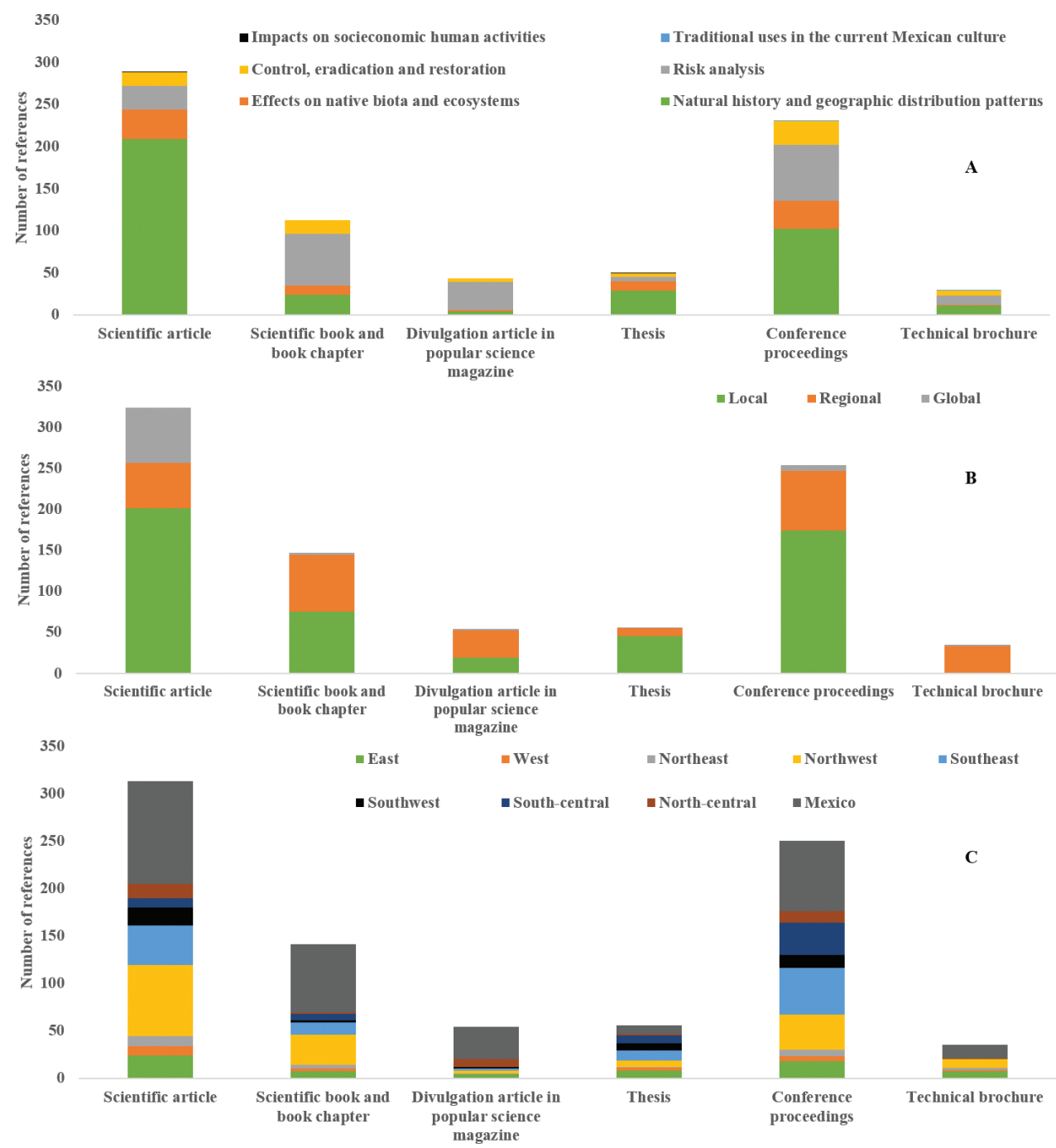

Figure 2. Distribution of references on biological invasions in Mexico per publication type and $\mathbf{A}$ main topic B scope study and $\mathbf{C}$ study region in Mexico.

threaten farmland and the Armored catfish (Pterygoplichthys spp.), which affects aquaculture operations. Other studies focused on the control and eradication of alien species such as insects and arachnids that act as pests and damage crops of economic importance, such as corn, citrus, bean, coffee, avocado, cotton and mango crops, amongst others, as well as forest plantations. Studies on the control and eradication of invasive species were mainly carried out in natural protected areas or wetlands, including the eradication of rodents on islands. Additional studies assessed the use of bio-insecticides or bio-pesticides for controlling agricultural pests. However, as mentioned, the largest number of references focused on the natural history and geographic distribution patterns of alien species, mainly based 
Table 3. Information provided by the reference according to Quiroz et al. (2009) and Richardson and Rejmănek (2011).

\begin{tabular}{|c|c|c|c|c|c|c|}
\hline & $\begin{array}{c}\text { Scientific } \\
\text { article }\end{array}$ & $\begin{array}{c}\text { Scientific book } \\
\text { and book chapter }\end{array}$ & $\begin{array}{c}\text { Divulgation article in } \\
\text { popular science magazine }\end{array}$ & Thesis & $\begin{array}{l}\text { Conference } \\
\text { proceedings }\end{array}$ & $\begin{array}{l}\text { Technical } \\
\text { brochure }\end{array}$ \\
\hline $\begin{array}{l}\text { Actors' organisation } \\
\text { and perception }\end{array}$ & 4 & 19 & 6 & 2 & 18 & 5 \\
\hline Adaptative evolution & 3 & & & 3 & 4 & 2 \\
\hline Allelopathy & 1 & & & 1 & 2 & \\
\hline $\begin{array}{l}\text { Biocontrol } \\
\text { techniques }\end{array}$ & 11 & 7 & 1 & 1 & 18 & 2 \\
\hline Biological data & 6 & 1 & & 4 & 7 & \\
\hline $\begin{array}{l}\text { Biotic } \\
\text { homogenisation }\end{array}$ & 2 & 1 & & 1 & 1 & \\
\hline Checklist & 5 & 12 & 3 & & 9 & 5 \\
\hline Current status & 27 & 13 & 3 & 2 & 10 & 3 \\
\hline $\begin{array}{l}\text { Ecological and } \\
\text { socioeconomic } \\
\text { impacts }\end{array}$ & 15 & 15 & 5 & 2 & 22 & 2 \\
\hline $\begin{array}{l}\text { Ecological and } \\
\text { socioeconomic } \\
\text { knowledge }\end{array}$ & 1 & 5 & & & 4 & 1 \\
\hline Ecological niche & 14 & & & 1 & & \\
\hline $\begin{array}{l}\text { Geographical } \\
\text { distribution patterns }\end{array}$ & 46 & 1 & & & 11 & 5 \\
\hline Habitat use & & & & & 6 & \\
\hline Human use & 1 & 2 & 2 & & 4 & \\
\hline $\begin{array}{l}\text { Interspecific } \\
\text { interactions }\end{array}$ & 22 & 3 & & & 20 & 9 \\
\hline Invasive process & 16 & 7 & 3 & 1 & 8 & 1 \\
\hline $\begin{array}{l}\text { New record of } \\
\text { geographical } \\
\text { distribution }\end{array}$ & 38 & 2 & & & 9 & \\
\hline $\begin{array}{l}\text { Novel monitoring } \\
\text { techniques }\end{array}$ & 4 & 3 & 2 & & 6 & 2 \\
\hline Phylogeny & & 1 & & & 1 & \\
\hline Population dynamics & 15 & 2 & & 5 & 18 & \\
\hline Population genetics & 4 & & & 1 & 3 & \\
\hline Reproductive success & 15 & & 1 & 5 & 13 & \\
\hline Restoration & 5 & 6 & 1 & & 5 & 1 \\
\hline Risk analysis & 10 & 9 & 15 & 2 & 18 & 3 \\
\hline
\end{tabular}

on presence records. Several additional studies focused on autecology, interactions with native species and geographic patterns and ranges. Numerous studies addressed biological invasion from different perspectives or performed risk analysis to determine the possible impacts of invasive species, identify potential risk areas or outline the prospects for the management of invasive species, as well as policies and strategies for their control. Finally, most studies had a local scope $(\mathrm{n}=533)$ followed by a regional $(\mathrm{n}=251)$ and global scope $(\mathrm{n}=82$, Fig. 2B). Of the local studies, most were carried out in the north-western region of Mexico $(n=162)$ followed by the south-eastern $(n=116)$ and eastern regions $(n=68)$ 
(Fig. 2C). The scope of the study varied significantly amongst reference types, with significant heterogeneity in terms of their scope study (chi-square $=203.72, d f=2, p<0.001$ ) and study region (chi-square $=136.82, d f=8, p<0.001$ ). In both cases, most references were of local and regional scope, in specific north-western and south-western Mexican regions, while western and north-eastern Mexican region had few references.

Moreover, a total of 510 references focused on one or two species; of these, 164 corresponded with vascular plants, 66 with insects and arachnids, 60 with birds and 118 with fishes. Notably, 213 references focused on the ecological and socio-economic aspects of only eight notorious invasive alien species in Mexico: the Indo-Pacific lionfish (Pterois volitans), the Monk parakeet (Myiopsitta monachus), the Armored catfish (Pterygoplichthys spp.), Buffelgrass (Pennisetum ciliare), Kalanchoes (Kalanchoe spp.), Antelope grass (Echinochloa pyramidalis), Eurasian collared dove (Streptopelia decaocto) and the Cactus moth (Cactoblastis cactorum). On the other hand, there were few studies on feral cats, feral dogs, rodents (Rattus rattus, $R$. norvergicus and Mus musculus) and the Common carp (Cyprinus carpio), as well as other widely distributed invasive species such as Eucalypti (Eucalyptus spp.), Pampas grass (Cortadeira selloana) and the Red-bay ambrosia beetle (Xyleborus glabratus), which pose a high risk to native biota, socio-economic activities and human health (e.g. Zambrano et al. 2010; Lira-Noriega et al. 2018).

\section{Discussion and conclusions}

The present review is the first comprehensive compilation of studies on biological invasion in Mexico (see Suppl material 1: Appendix S1) and presents the first overall assessment of the knowledge of biological invasions according to the area of study and main research topics and regions. Only one previous review, focusing on the biological invasion of non-native weeds in Mexico, identified 229 publications (scientific articles and books) (Espinosa-García and Villaseñor 2017). Ten notable findings can be highlighted: (i) One of the earlier scientific studies on biological invasion was performed by Itie $(1939,1945)$ on California grass [Brachiaria mutica (Forssk.) Stapf.] and Natal grass [Rhynchelytrum repens (Willd.) Zizka], which were introduced as forage in Mexico. (ii) Several years later, Rzedowski (1959) described the presence of Russian thistle (Salsola kali var. tenuifolia) in central Mexico. (iii) Several decades later, Rzedowski and Calderón-de Rzedowski $(1979,1985)$ published the Flora Fanerogámica del Valle de México (The Phanerogamic Flora of the Valley of Mexico in English) and Flora del Bajío (The Flora of the Lowlands in English), in which the presence of several invasive species was recognised. (iv) More recently, Villaseñor and Espinosa-García (2004) made an important contribution to the knowledge of alien plant richness in Mexico. (v) Álvarez-Romero et al. (2008) presented a review of the ecology, distribution, impacts and control of exotic vertebrates in Mexico. ( $v i$ ) In addition, Aguirre-Muñoz et al. (2009) conducted a review of alien species and their impacts on native biota and human activities. (vii) Most recently, the National Strategy for the Prevention, Control and Eradication of Invasive Species was established to monitor and control 
invasive species in Mexico (Comité Asesor Nacional sobre Especies Invasoras 2010). (viii) Haemig $(2012,2014)$ described perhaps the first documented case of an invasive species in Mexico wherein the Great-tailed grackle (Quiscalus mexicanus), originally from the coastal plain of the Gulf of Mexico, was introduced to the Valley of Mexico by the Aztec emperor Auitzotl (1486-1502). (ix) Espinosa-García and Villaseñor (2017) then briefly reviewed current knowledge of the richness, ecology, distribution and management of non-native weeds in Mexico and provided some data on their possible environmental and economic impacts, identifying approximately 700 wild alien species and 229 related references in Mexico. Lastly, $(x)$ Born-Schmidt et al. (2017) summarised the main challenges facing Mexico in combating invasive alien species.

Generally, research on biological invasions in Mexico was scarce during the last two decades of the latter century. However, research substantially increased during the first decade of the $21^{\text {st }}$ century and this trend continues today (Figure 1). Therefore, the study of biological invasions may be considered an emerging discipline in Mexico that has grown in recent years. Mexico is one of the four Latin American countries with the greatest scientific productivity with regard to biological invasions yet, comparatively, the number of references for Mexico is relatively low if we take into account the scientific references indexed in the Web of Knowledge: 105 references were found for Argentina from 1988 to 2008 (Pauchard et al. 2011), 354 for Brazil from 1991 to 2013 (Frehse et al. 2016) and 92 for Chile from 1991 to 2008 (Quiroz et al. 2009; Pauchard et al. 2011). The number of studies is also particularly low compared to that generated in countries like the United States, Australia and New Zealand (Nuñez and Pauchard 2010).

When we compared studies in Mexico with those in other regions of the world, we identified several topics that should be more thoroughly addressed by Mexican ecologists: demographic patterns, behavioural ecology, interactions with native species, population genetics and adaptive processes. The scarcity of historical references is likely since the study of biological invasions in Mexico did not attract the interest of ecologists until the late 1990s. During this period, biological invasions began to be recognised by the scientific community and society in general given the increasing rate, scale and magnitude of anthropogenic activities and their effects on ecosystems (Vitousek et al. 1997a, 1997b). The ecology of invasive species was consolidated in the late 1990s as a sub-discipline of ecology and an increasing number of studies on biological invasions were performed during that decade. So finally, from the year 2000, the concept of biological invasions was introduced into environmental decision-making.

Despite the increasing number of studies on invasive species in Mexico over the last two decades, there are several pending challenges. A significant number of studies solely focus on the natural history and geographical distribution patterns of invasive species or distinct perspectives and risk analysis. However, to improve the understanding of biological invasions and their impacts, it is necessary to examine in greater depth the effects of invasive species on native biota and ecosystems, including the effects in terms of restoration and socioeconomic costs (Quiroz et al. 2009). Such research could potentially identify new possibilities for the management and control of invasive species based on their behaviour and the mechanisms related to their invasion. In this 
regard, further experimental studies are necessary in addition to early research studies to anticipate potential invasions that could be harmful to biodiversity and human productive activities. It is also important to carry out further research geared towards implementing measures or programmes to control or eradicate alien species (Temple 1990). In addition, there is a lack of studies on the potential hazards that cause alien species to "drive" other alien species and the potential uses (ornamental, forestry, recreational or food) of invasive species.

According to Espinosa-García and Villaseñor (2017), research on biological invasions in Mexico follows a prevalent pattern in which research is produced by only a few academic groups and is mostly disarticulated. Only on a few occasions have the results of such research studies been communicated with decision-makers in governmental agencies such as CONABIO, one of the world's most recognised sources for information on biodiversity, which also created the Information System on Invasive Species in Mexico (CONABIO 2018) and the National Strategy for Biological Invasions (Comité Asesor Nacional sobre Especies Invasoras 2010). In this regard, the knowledge generated by national scientific institutions should relate to national and global initiatives (e.g. GloNAF, GBIF, GISP and GRIIS) in order to coordinate efforts on the different topics identified in the National Strategy for Biological Invasions (Comité Asesor Nacional sobre Especies Invasoras 2010). It would be important for such efforts to consider available information on alien or invasive species in different scientific publications (e.g. scientific articles, theses etc.). One final task is the standardisation of the criteria for determining the current status and categorisation of invasive or naturalised species.

Currently, biological invasions are altering the functioning of natural ecosystems in a way that is unprecedented in the history of our planet, leading to substantial economic losses in many countries (Hulme 2009). Mexico is not immune to this problem. However, the scarcity of scientific information on some topics in Mexico regarding biological invasions, including the number of invasive species and the status of alien species, makes it difficult to predict the magnitude of their impacts on native biota and ecosystems. Furthermore, this lack of information prevents the development of efficient management, control and eradication plans. Therefore, the current gaps in the knowledge of biological invasions in Mexico outlined in the present review can help to prioritise future research studies. In particular, the challenges of future research studies include defining national priorities for controlling invasive alien species and examining previously unexplored topics, such as interspecific interactions with native biota, food habits, habitat use, adaptative evolution and geographical distribution under climate change.

\section{Acknowledgements}

Thanks to Instituto Potosino de Investigación Científica y Tecnológica. JERA was supported by doctoral grant (CONACyT-169631) and also was supported by mixed scholarship programme (CONACyT-290749). 


\section{References}

Aguirre-Muñoz A, Mendoza R, Arredondo H, Arriaga L, Campos E, Contreras-Balderas S, Gutiérrez E, Espinosa-García FJ, Fernández I, Galaviz L, García FJ, Lazcano D, Martínez M, Meave ME, Medellín R, Naranjo E, Olivera MT, Pérez M, Rodríguez G, Salgado G, Samaniego A, Suárez E, Vibrans H, Zertuche JA (2009) Especies exóticas invasoras: impactos sobre las poblaciones de flora y fauna, los procesos ecológicos y la economía. In: CONABIO (Eds) Capital natural de México, vol. II: estado de conservación y tendencias de cambio. CONABIO. México, 277-318.

Álvarez-Romero JG, Medellín RA, Oliveras de Ita A, Gómez de Silva H, Sánchez O (2008) Animales exóticos en México: una amenaza para la biodiversidad. CONABIO-Instituto de Ecología, UNAM-SEMARNAT. México, D.F.

Born-Schmidt G, Alba F, Parpal J, Koleff P (2017) Principales retos que enfrenta México ante las especies exóticas invasoras. CESOP, México.

Calderón-de Rzedowski G, Rzedowski J (1979) Flora fanerogámica del Valle de México. Ed. Continental. México.

Challenger A, Caballero J (1998) Utilización y conservación de los ecosistemas terrestres de México: pasado presente y futuro. CONABIO-Instituto de Biología, UNAM-Agrupación Sierra Madre. México, D.F.

Charles H, Dukes JS (2007) Impacts of invasive species on ecosystem services. In: Nentwig W (Ed.) Biological Invasions, Springer-Verlag, Berlin-Heidelberg, 217-237. https://doi. org/10.1007/978-3-540-36920-2_13

Comité Asesor Nacional sobre Especies Invasoras (2010) Estrategia Nacional sobre Especies Invasoras en México. Prevención, control y erradicación. CONABIO-CONANP-SEMARNAT. México.

CONABIO (National Commission for the Knowledge and Use of Biodiversity of Mexico) (2018) Sistema de información sobre especies invasoras en México. CONABIO. http:// www.biodiversidad.gob.mx/especies/invasoras/

D'Antonio CM, Vitousek PM (1992) Biological invasions by exotic grasses, the grass/fire cycle, and global change. Annual Review of Ecology, Evolution, and Systematics 23: 63-87. https://doi.org/10.1146/annurev.es.23.110192.000431

Elton CS (1958) The ecology of invasions by animals and plants. Chapman \& Hall Ltd. Chicago. https://doi.org/10.1007/978-1-4899-7214-9

Espinosa-García FJ (2008) Invasive weeds in Mexico: overview of awareness, management and legal aspects. In: Darbyshire SJ, Prasad R (Ed.) Proceedings of the Weeds across Borders 2008 Conference. Alberta, 17-29.

Espinosa-García FJ, Villaseñor JL (2017) Biodiversity, distribution, ecology and management of non-native weeds in Mexico: a review. Revista Mexicana de Biodiversidad 88: 76-96. https://doi.org/10.1016/j.rmb.2017.10.010

Frehse F, Braga RR, Nocera GA, Vitule JRS (2016) Non-native species and invasion biology in a megadiverse country: scientometric analysis and ecological interactions in Brazil. Biological Invasions 18: 3713-3725. https://doi.org/10.1007/s10530-016-1260-9 
Haemig PD (2012) Introduction of the Great-tailed grackle Quiscalus mexicanus by Aztec Emperor Auitzotl: provenance of the historical account. Auk 1291: 70-75. https://doi. org/10.1525/auk.2011.11058

Haemig PD (2014) Aztec introduction of the Great-tailed grackle in ancient Mesoamerica: formal defense of the Schaguntine historical account. Neobiota 22: 59-75. https://doi. org/10.3897/neobiota.226791

Heenan PB, Breitwieser I, Glenny DS, De Lange PJ, Brownsey PJ (1998) Checklist of dicotyledons and pteridophytes naturalized or casual in New Zealand: additional records 1994-96. New Zealand Journal of Botany 36: 155-162.

Hulme PE (2009) Trade, transport and trouble: managing invasive species pathways in an era of globalization. Journal of Applied Ecology 46: 10-18. https://doi.org/10.1111/j.13652664.2008.01600.x

Itié G (1939) Introducción del zacate pará, Panicum purpurascens Raddi. en México y área de dispersión del mismo. Revista de la Sociedad Mexicana de Historia Natural 1:29-32.

Itié G (1945) Un zacate emigrante (Tricholaena rosea Nees). Boletín de la Sociedad Botánica Mexicana 2: 19-20. https://doi.org/10.17129/botsci.920

Lin W, Zhou G, Cheng X, Xu R (2007) Fast economic development accelerates biological invasions in China. PLoS ONE 2: e1208. https://doi.org/10.1371/journal.pone.0001208

Lira.Noriega A, Soberón J, Equihua J (2018) Potential invasion of exotic ambrosia beetles Xyleborus glabratus and Euwallacea sp. in Mexico: a major threat for native and cultivated forest ecosystems. Scientific reports 8:10179. https://doi.org/10.1039/541598-018-28517-4

MacIsaac HJ, Tedla RA, Ricciardi A (2011) Patterns and rate of growth of studies in invasion ecology. In: Richardson DM (Ed.) Fifty years of invasion ecology: the legacy of Charles Elton. Blackwell Publishing Ltd. Chicago, 51-60. https://doi.org/10.1002/9781444329988.ch5

Meyerson LA, Mooney HA (2007) Invasive alien species in an era of globalization. Frontiers in Ecology and the Environment 5: 199-208. https://doi.org/10.1890/15409295(2007)5[199:IASIAE]2.0.CO;2

Mittermeier RA, Robles-Gil P, Mittermeier CG (1997) Megadiversity. CEMEX. Mexico.

Nuñez MA, Pauchard A (2010) Biological invasions in developing and developed countries: does one model fit all? Biological Invasions 12: 707-714. https://doi.org/10.1007/s10530-009-9517-1

Pauchard A, Quiroz C, García R, Anderson CH, Kalin M (2011) Invasiones biológicas en América Latina y el Caribe: tendencias en investigación para la conservación, In: Simonetti J, Dirzo R (Ed.) Conservación Bilógica: Perspectivas desde América Latina. Edit. Universitaria, Santiago Chile, 79-94.

Pyšek P, Richardson DM (2006) The biogeography of naturalization in alien plants. Journal of Biogeography 33: 2040-2050. https://doi.org/10.1111/j.1365-2699.2006.01578.x

Quiroz CL, Pauchard A, Cavieres LA, Anderson CB (2009) Análisis cuantitativo de la investigación en invasiones biológicas en Chile: tendencias y desafíos. Revista Chilena de Historia Natural 82: 497-505. https://doi.org/10.4067/S0716-078X2009000400005

Rejmănek M, Richardson DM (1996) What attributes make some plant species more invasive? Ecology 77: 1655-1661. https://doi.org/10.2307/2265768

Richardson DM, Rejmănek M (2011) Trees and shrubs as invasive alien species -a global review. Diversity and Distributions 17: 788-809. https://doi.org/10.1111/j.14724642.2011.00782.x 
Richardson DM, Carruthers J, Hui C, Impson FAC, Miller JT, Robertson MP, Rouget M, Le Roux JJ, Wilson JRU (2011) Human-mediated introductions of Australian acacias-a global experiment in biogeography. Diversity and Distributions 17: 771-787. https://doi. org/10.1111/j.1472-4642.2011.00824.x

Rzedowski J (1959) Salsola kali var. tenuifolia: una peligrosa maleza exótica que está extendiendose hacia el centro de México. Boletín de la Sociedad Botánica Mexicana 24: 53-59. https://doi.org/10.17129/botsci.1061

Rzedowski J, Calderón-de Rzedowski G (1985) Flora del Bajío y regiones adyacentes. Pátzcuaro, Michoacán: Instituto de Ecología, A.C.

Temple SA (1990) The nasty necessity: eradicating exotics. Conservation Biology 4: 113-115. https://doi.org/10.1111/j.1523-1739.1990.tb00096.x

Villaseñor JL, Espinosa-García FJ (2004) The alien flowering plants of Mexico. Diversity and Distributions 10: 113-123. https://doi.org/10.1111/j.1366-9516.2004.00059.x

Vitousek PM (1990) Biological invasions and ecosystem processes: towards an integration of population biology and ecosystem studies. Oikos 57: 7-13. https://doi.org/10.2307/3565731

Vitousek PM, Mooney HA, Lubchenco J, Melillo JM (1997a) Human domination of Earth's ecosystem. Science 277: 494-499. https://doi.org/10.1126/science.277.5325.494

Vitousek PM, Mooney HA, Lubchenco J, Melillo JM (1997b) Introduced species: A significant component of human-caused global change. New Zealand Journal of Ecology 21: 1-16.

Wilcove DS, Rothstein D, Dubow J, Phillips A, Losos E (1998) Quantifying threats to imperiled species in the United States. Bioscience 48: 607-615. https://doi.org/10.2307/1313420

Zambrano L, Valiente E, Vander MJ (2010) Food web overlap among native axolotl (Ambystoma mexicanum) and two exotic fishes: carp (Cyprinus carpio) and tilapia (Oreochromis niloticus) in Xochimilco, Mexico City. Biological Invasions 12: 3061-3069. https://doi. org/10.1007/s10530-010-9697-8

Zar J (1999) Biostatistical analysis. New Jersey, Prentice-Hall.

\section{Supplementary material I}

Appendix S1. Reference database on biological invasions in Mexico $(\mathrm{N}=869)$. Authors: Jorge E. Ramírez-Albores, Ernesto I. Badano, Joel Flores, José Luis FloresFlores, Laura Yánez-Espinosa

Data type: species data

Explanation note: This database included all the bibliographic references with main topic, information provided by the reference, species group, publication type, scope study, study region and language. $\left({ }^{*}\right)$ The study was realised in natural protected areas and $(\ddagger)$ the study was realised on an island.

Copyright notice: This dataset is made available under the Open Database License (http://opendatacommons.org/licenses/odbl/1.0/). The Open Database License $(\mathrm{ODbL})$ is a license agreement intended to allow users to freely share, modify, and use this Dataset while maintaining this same freedom for others, provided that the original source and author(s) are credited.

Link: https://doi.org/10.3897/neobiota.48.36201.suppl1 